\title{
RARA Positive
}

National Cancer Institute

\section{Source}

National Cancer Institute. RARA Positive. NCI Thesaurus. Code C146655.

An indication that RARA expression has been detected in a sample. 